\title{
Evaluation of novel SNPs and haplotypes within the ATBF1 gene and their effects on economically important production traits in cattle
}

\author{
Han Xu, Sihuan Zhang, Xiaoyan Zhang, Ruihua Dang, Chuzhao Lei, Hong Chen, and Xianyong Lan \\ College of Animal Science and Technology, Northwest A\&F University, Shaanxi Key Laboratory of Molecular \\ Biology for Agriculture, Yangling, Shaanxi 712100, China \\ Correspondence to: Xianyong Lan (lanxianyong79@126.com) and Hong Chen (chenhong1212@126.com) \\ Received: 14 April 2017 - Revised: 10 July 2017 - Accepted: 24 July 2017 - Published: 29 August 2017
}

\begin{abstract}
AT motif binding factor $1(A T B F 1)$ gene can promote the expression level of the growth hormone 1 (GHl) gene by binding to the enhancers of the POUIF1 and PROPI genes; thus, it affects the growth and development of livestock. Considering that the ATBF1 gene also has a close relationship with the Janus kinasesignal transductor and activator of transcription (JAK-STAT) pathway, the objective of this work was to identify novel single-nucleotide polymorphism (SNP) variations and their association with growth traits in native Chinese cattle breeds. Five novel SNPs within the ATBF1 gene were found in 644 Qinchuan and Jinnan cattle for first time using 25 pairs of screening and genotyping primers. The five novel SNPs were named as AC_000175:g.140344C $>$ G (SNP1), g.146573T >C (SNP2), g.205468C $>$ T (SNP3), g.205575A $>$ G (SNP4) and g.297690C $<$ T (SNP5). Among them, SNP1 and SNP2 were synonymous coding SNPs, while SNP5 was a missense coding SNP, and the other SNPs were intronic. Haplotype analysis found 18 haplotypes in the two breeds, and three and five closely linked loci were revealed in Qinchuan and Jinnan breeds, respectively. Association analysis revealed that SNP1 was significantly associated with the height across the hip in Qinchuan cattle. SNP2 was found to be significantly related to chest circumference and body side length traits in Jinnan cattle. SNP3 was found to have significant associations with four growth traits in Qinchuan cattle. Moreover, the different combined genotypes, SNP1-SNP3, SNP1-SNP4 and SNP2-SNP5 were significantly associated with the growth traits in cattle. These findings indicated that the bovine ATBF1 gene had marked effects on growth traits, and the growth-trait-related loci can be used as DNA markers for maker-assisted selection (MAS) breeding programs in cattle.
\end{abstract}

\section{Introduction}

With the fast improvement in living standards in developing countries, especially China, the demand for beef consumption has increased quickly. Although cattle breed resources are very abundant in China, poor quality and low growth rate of many breeds are still barriers to an increase in cattle production. It is difficult to meet our needs and improve the breeding speed by using traditional methods; thus, the efficient genetical methods, such as DNA marker-assisted selection (MAS), should be used to improve the efficiency of production and lay the foundation for breeding new breeds (Pedersen et al., 2009). As the most practical and economic method, the MAS strategy relies on the numerous singlenucleotide polymorphisms (SNPs) associated with production traits. Therefore, more functional SNPs, which could be applied in MAS breeding of domestic livestock, should be discovered. An example is the single A-to-G substitution near the ovine $C L P G$ gene, which has been used for doublemuscle livestock breeding (Cockett et al., 1994).

The AT motif binding factor $1(A T B F 1)$ gene encodes a transcription factor with multiple homeodomains and zinc finger motifs; thus, it is also named zinc finger homeobox 3 (ZFHX3). ATBF1 was first isolated as an AT (adenine and thymine)-binding factor of human $\alpha$-fetoprotein (AFP) (Morinaga et al., 1991). It was reported to function as a tu- 
mor suppressor in several cancers (Kawaguchi et al., 2016; Sun et al., 2014, 2015). More importantly, it plays an important role in regulating myogenesis, adipose tissue development and transactivating the cell cycle inhibitor (Jung et al., 2005; Postigo and Dean, 1997, 1999; Richard and Stephens, 2014).

Furthermore, ATBF1 could promote the expression level of the growth hormone $1(G H 1)$ gene by binding to the enhancers of the POUIFI and PROPI genes (Araujo et al., 2013; Qi et al., 2008), which are the key genes in mammalian growth, development and the lactationrelated hypothalamic-pituitary-adrenal (HPA) axis pathway (PITX2/PITX1 - HESX1 - LHX3/LHX4 - PROP1 POU1F1) (Davis et al., 2010; Ma et al., 2017). In addition, another key gene in the HPA axis pathway, PITX2, has a positive regulation relationship with $A T B F 1$ under the participation of miR-1 (Huang et al., 2015).

Meanwhile, ATBF1 has close relationships with STAT family genes, which are growth-related genes. STAT3 and STAT5A are two key genes in Janus kinase-signal transducer and activator of transcription pathway (JAK-STAT), and JAK-STAT is responsible for promoting the secretion of a variety of cytokines, growth factors and $\mathrm{GHI}$ (Herrington et al., 2000; Liongue and Ward, 2013; Trovato et al., 2012). $A T B F 1$ could enhance the suppression of STAT3 signaling by interaction with PIAS3, which is a protein inhibitor of the activated STAT family (Lao et al., 2016; Nojiri et al., 2004; S. F. Yang et al., 2016). Thus, it was surmised that the $A T B F 1$ gene plays an important role in regulating mammalian growth and development.

SNP research is a crucial step for the application of the genome project in human and MAS breeding in mammals. The genes mentioned above, CLPG, STAT3, STAT5A, $P O U 1 F 1$ and PROP1, all have SNPs associated with growth traits, and some SNP genotypes were found to be significantly associated with mRNA expression levels (Jia et al., 2015; Lan et al., 2007, 2009; Wu et al., 2014; Zhao et al., 2013). In humans, functional SNPs that were associated with disease were found in the ATBF1 gene (Liu et al., 2014; Tsai et al., 2015). Moreover, four SNPs that were significantly associated with goat growth traits were identified in the goat ATBFl gene (Zhang et al., 2015b).

Considering the important roles of the $A T B F 1$ gene in the HPA axis and JAK-STAT pathways, which are related to mammalian growth and development, and the significance of SNP in biological process and livestock breeding, the purpose of this study was to identify crucial SNP variations within the ATBF1 gene in native Chinese cattle breeds. This will also help to promote the understanding of $A T B F 1$ gene function and better apply the excellent local cattle germplasm resources in cattle MAS breeding.

\section{Materials and methods}

\subsection{Animal samples and data collection}

Experimental animal samples used in this study were approved by the Faculty Animal Policy and Welfare Committee of Northwest A\&F University under contract. The care and use of experimental animals fully complied with local animal welfare laws, guidelines and policies.

A total of 644 blood samples were collected from healthy and unrelated adult cattle belonging to two well-known Chinese native cattle breeds, Qinchuan cattle (459) and Jinnan cattle (185). All Qinchuan individuals were reared in a native breeding farm in Fufeng County, Shaanxi Province. Jinnan individuals were reared on a Yuncheng cattle farm in Shanxi Province.

The growth trait data of the Qinchuan cattle were collected from the Qinchuan breeding farm, including body weight, body height, body length, chest circumference, hucklebone width, height across the hip, chest width, chest depth, rump length and hip width. The growth trait data of the Jinnan cattle, including body height, height across the hip, chest circumference, rump length and body side length, were collected from the Jinnan cattle farm. All growth trait data were measured as described by Zhang et al. (2015a).

\subsection{DNA isolation and genomic DNA pool construction}

Genomic DNA samples were extracted from the leukocytes of the blood samples as described by Dang et al. (2014). All genomic DNA samples were diluted to the working concentration $50 \mathrm{ng} \mu \mathrm{L}^{-1}$ for the DNA pool construction and polymerase chain reaction (PCR) amplification. To construct DNA pools, 30 DNA samples were randomly and selected from the Qinchuan and Jinnan cattle. The two DNA pools were used as templates for PCR amplification, and the product of amplification was used to sequence and explore genetic variations in the $A T B F 1$ gene.

\subsection{Primer design and PCR amplification for SNP screening}

To expose novel SNPs in the bovine ATBF1 gene, 20 pairs of primer were designed using the Primer Premier 5 software based on the bovine ATBFI gene DNA sequence (NCBI reference sequence: AC_000175.1) (Table 1). The $25 \mu \mathrm{L}$ PCR reaction volume includes $50 \mathrm{ng}$ of genomic DNA from the DNA pool, $0.5 \mu \mathrm{M}$ of each primer and $12.5 \mu \mathrm{L} 2 \times$ EcoTaq PCR SuperMix (+dye) (Beijing TransGen Biotech Co., Ltd., Beijing, China). The touchdown PCR program was executed as follows: pre-denaturation at $95^{\circ} \mathrm{C}$ for $4 \mathrm{~min}$, followed by 18 cycles of denaturation at $94^{\circ} \mathrm{C}$ for $30 \mathrm{~s}$, annealing at $68^{\circ} \mathrm{C}$ for $30 \mathrm{~s}$ (decreased by $1^{\circ} \mathrm{C}$ per cycle) and extending at $72^{\circ} \mathrm{C}$ for $1 \mathrm{~kb} \mathrm{~min}^{-1}$, then another 22 cycles at $94^{\circ} \mathrm{C}$ for $30 \mathrm{~s}$, $50^{\circ} \mathrm{C}$ for $30 \mathrm{~s}$ and $72^{\circ} \mathrm{C}$ for $1 \mathrm{~kb} \mathrm{~min}^{-1}$, finally extending 

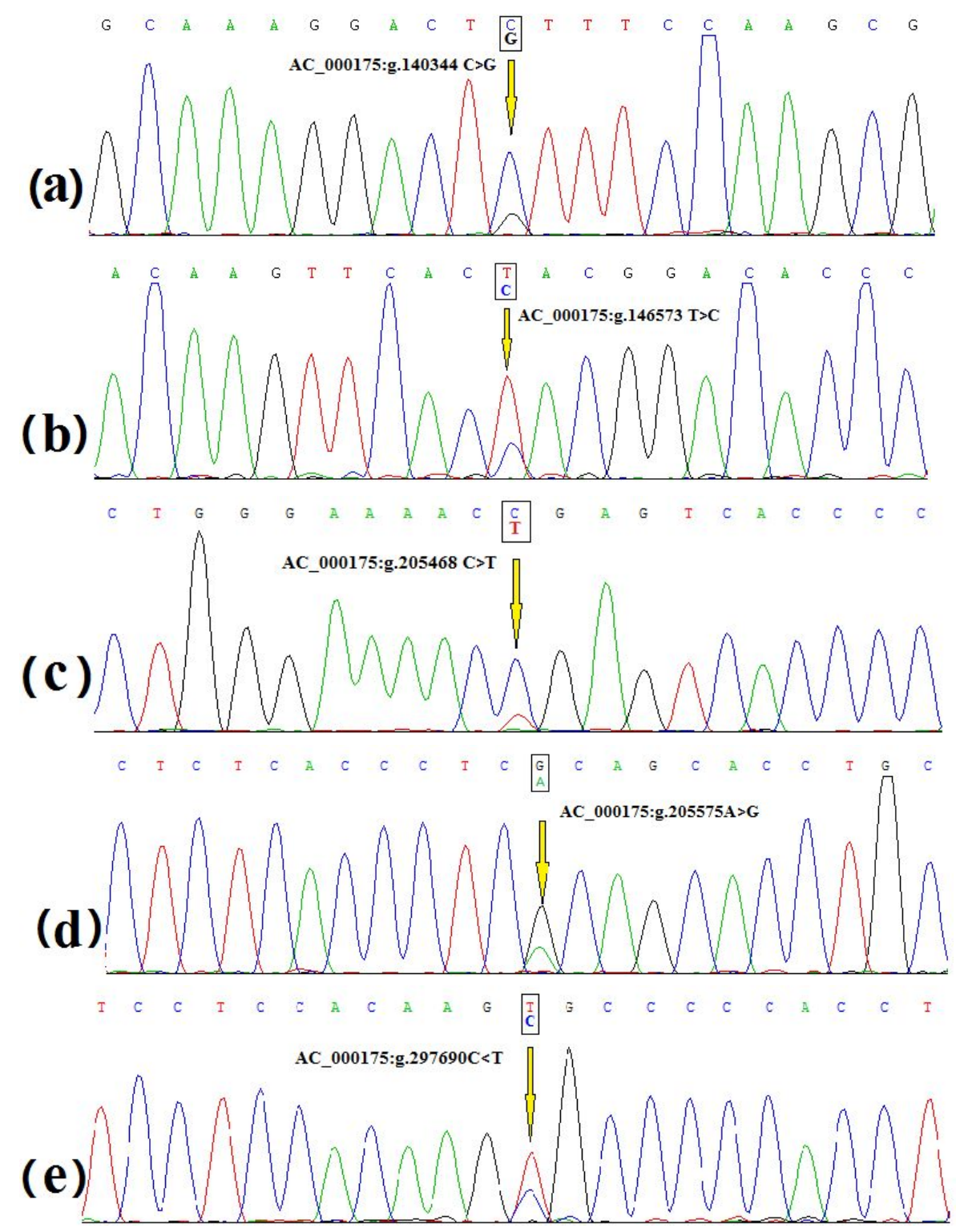

Figure 1. Sequence chromas of five novel SNP loci in the bovine ATBF1 gene. Note: panels (a), (b), (c), (d) and (e) represent the pooling sequence chromas of SNP1, SNP2, SNP3, SNP4 and SNP5, respectively.

at $72^{\circ} \mathrm{C}$ for $10 \mathrm{~min}$. The products of PCR amplification were sequenced to screen the SNP loci.

\subsection{Primer design and genotyping by PCR-RFLP, forced PCR-RFLP and T-ARMS-PCR methods}

DNA pool sequencing and sequence analysis identified five novel SNPs within the Qinchuan and Jinnan bovine ATBF1 gene, namely, AC_000175:g.140344C $>\mathrm{G}$ (SNP1), g.146573T $>\mathrm{C}$ (SNP2), g.205468C $>\mathrm{T} \quad$ (SNP3), g.205575A $>$ G (SNP4) and g.297690C $<$ T (SNP5) (Fig. 1). According to the sequencing results, PCR restriction fragment length polymorphism (PCR-RFLP), forced PCR-RFLP and tetra-primer amplification refractory mutation system PCR (T-ARMS-PCR) methods were used to detect genotypes of Qinchuan and Jinnan individuals (Table 2). The primers of PCR-RFLP and forced PCR-RFLP were designed by the Primer Premier 5 software, and T-ARMS-PCR primers were designed on the Primer1 website (http://primer1.soton.ac.uk/ primer1.html) (Collins, 2012; Ye et al., 2001). The genotyping methods used on different SNP loci were introduced as below:

SNPs genotyped with the PCR-RFLP and forced PCRRFLP methods: SNP3 and SNP5 were detected using the PCR-RFLP method, and the PCR amplification products were digested with DdeI and HhaI restriction enzymes. SNP2 
Table 1. Amplification PCR primers for screening the novel SNPs within the bovine ATBF1 gene; bp: base pair.

\begin{tabular}{|c|c|c|c|}
\hline Names & Primer sequences $\left(5^{\prime} \rightarrow 3^{\prime}\right)$ & Product sizes (bp) & Location \\
\hline \multirow[t]{2}{*}{ P1 } & F: GAAAGGGCTTCTCCTGACG & 367 & Intron 1 \\
\hline & R: GATACCGCACCCATTGTCC & & \\
\hline \multirow[t]{2}{*}{$\mathrm{P} 2$} & F: CCTGACTCTAACGCTGTGCT & 1264 & Exon 2 \\
\hline & R: GGATGGGCTTCCTCTTGC & & \\
\hline \multirow[t]{2}{*}{ P3 } & F: CTTTCCACATAGCCTCATCCTT & 1202 & Exon 2 \\
\hline & R: TTTATTGGCACTTTCATCAGCA & & \\
\hline \multirow[t]{2}{*}{ P4 } & F: TGCTGATGAAAGTGCCAATA & 1116 & Exon 2 \\
\hline & R: GAGCATCCAGTCGTCCCTT & & \\
\hline \multirow[t]{2}{*}{ P5 } & F: GTGTCAGGTGTCCCATAGCC & 1153 & Exon 3 \\
\hline & R: AATGCCAGTCCCTCCAGTTA & & \\
\hline \multirow[t]{2}{*}{ P6 } & F: GATTATTGTGCCAGGAAGCC & 714 & Exon 4 \\
\hline & R: GATCTGAACCCAAAGACTGAA & & \\
\hline \multirow[t]{2}{*}{ P7 } & F: GCTCAGGCACCACGAAG & 1080 & Exon 5 \\
\hline & R: CAGGACACCAGGGATACAAA & & \\
\hline \multirow[t]{2}{*}{ P8 } & F: GACTCTTACCCAGCACGTACCCT & 1461 & Exon $(6+7)$ \\
\hline & R: TAACAGAAACCCACCATCCACAA & & \\
\hline \multirow[t]{2}{*}{ P9 } & F: CAGGACACCCTCTGGGCTAC & 1454 & Exon 8 \\
\hline & R: ATGGAGACATCATAAGGGAG & & \\
\hline \multirow[t]{2}{*}{$\mathrm{P} 10$} & F: CATTGGGCTTGATTTCTAT & 1138 & Exon 9 \\
\hline & R: GGTGGCATTCCTACACTTT & & \\
\hline \multirow[t]{2}{*}{ P11 } & F: CACCTTTACCACCACCAAC & 1442 & Exon 9 \\
\hline & R: TACGAGGCCGCTTATTCT & & \\
\hline \multirow[t]{2}{*}{ P12 } & F: GCCCATCTTCTCGCCACT & 802 & Exon 9 \\
\hline & R: ATCCTGCCCTTCCTCGTC & & \\
\hline \multirow[t]{2}{*}{ P13 } & F: CAGGATGACAGCCAGAATG & 680 & Exon 9 \\
\hline & R: CTTGCCAGCAGTGGGTTA & & \\
\hline \multirow[t]{2}{*}{ P14 } & F: TACAGCATCCTCTGCGTTCT & 1235 & Exon 9 \\
\hline & R: CCGTGCCTTCCACCTTGA & & \\
\hline \multirow[t]{2}{*}{ P15 } & F: GATGGCAATGTCTGAGTATGA & 1031 & Exon 9 \\
\hline & R: ACCCTGGTCTGTGCTGAA & & \\
\hline \multirow[t]{2}{*}{ P16 } & F: AACCGTCCTCAGCATCGC & 1457 & Exon 10 \\
\hline & R: CGTGTCAGACTCCTCCGAAT & & \\
\hline \multirow[t]{2}{*}{ P17 } & F: CGCTCACTCAAACGACAG & 1221 & Exon 10 \\
\hline & R: AATCTACTCAACACCGAAAA & & \\
\hline \multirow[t]{2}{*}{ P18 } & F: TTCTCAGGTCAATCGCTCAC & 1261 & Exon 10 \\
\hline & R: CACCGCTCAGACTGCCTA & & \\
\hline \multirow[t]{2}{*}{ P19 } & F: TGTTAGGCAGTCTGAGCG & 1409 & Exon 10 \\
\hline & R: TTCTGGGTTAATGTGGAG & & \\
\hline \multirow[t]{2}{*}{$\mathrm{P} 20$} & F: TTCTCCACATTAACCCAG & 1314 & Exon 10 \\
\hline & R: TCAGTCAGCTCCATCACC & & \\
\hline
\end{tabular}

was genotyped using the forced PCR-RFLP method, and the $\mathrm{C}$ nucleic acid on g.146575 was changed to $\mathrm{T}$ to make a locus that can be recognized by the EcoT14I (StyI) restriction enzyme. The PCR reaction volume for the two methods was $13 \mu \mathrm{L}$, including $25 \mathrm{ng}$ of genomic DNA, $0.2 \mu \mathrm{M}$ of each primer and $6.5 \mu \mathrm{L}$ of $2 \times$ EcoTaq PCR SuperMix (+dye). The amplification system was as follows: pre-denaturation at $95^{\circ} \mathrm{C}$ for $4 \mathrm{~min}$, followed by 35 cycles of denaturation at $94^{\circ} \mathrm{C}$ for $30 \mathrm{~s}$, optimal annealing temperature for $30 \mathrm{~s}$ and extending at $72{ }^{\circ} \mathrm{C}$ for $1 \mathrm{~kb} \mathrm{~min}-1$, finally extending at $72^{\circ} \mathrm{C}$ for $10 \mathrm{~min}$. Then the amplification products were digested with a special restriction enzyme and special temperature for
12 to $16 \mathrm{~h}$. The volume of digestion contains $2 \mathrm{U}$ ( $\mathrm{U}$ is unit of restriction enzyme) restriction enzyme, $2 \mu \mathrm{L}$ of $10 \times$ buffer, $10 \mu \mathrm{L}$ of PCR product and $6 \mu \mathrm{L}$ of distillation $\mathrm{H}_{2} \mathrm{O}$. Then the enzyme-digested products were genotyped using agarose gel electrophoresis. The electrophoretic band size and genotyping information are shown in Table 2.

SNPs genotyped with the T-ARMS-PCR method: SNP1 and SNP4 were genotyped using the T-ARMS-PCR method for failing to search for a suitable restriction enzyme. The special primers and genotyping information are exhibited in Table 2. The PCR reaction volume was $13 \mu \mathrm{L}$. The touchdown PCR program (from 68 to $50^{\circ} \mathrm{C}$; decreased by $1{ }^{\circ} \mathrm{C}$ 
Table 2. PCR primer sequences for $A T B F 1$ gene genotyping in cattle; bp: base pairs.

\begin{tabular}{|c|c|c|c|c|}
\hline Loci & Primer sequence $\left(5^{\prime} \rightarrow 3^{\prime}\right)$ & $\mathrm{AT}^{*}\left({ }^{\circ} \mathrm{C}\right)$ & Size (bp) & Detection method \\
\hline $\begin{array}{l}\text { P22-SNP2 } \\
(\text { g.146573T>C) }\end{array}$ & $\begin{array}{l}\text { F: GGGCAGTGCCTCAGGTAGGA } \\
\text { R: CAGCAGGTCCAGGGTGTCCATT }\end{array}$ & 61.7 & 231 & $\begin{array}{l}\text { Forced PCR-RFLP (EcoT14 I } \\
(\text { StyI }))(\mathrm{TT}=231 \mathrm{bp} \\
\mathrm{TC}=231+209+22 \mathrm{bp} \\
\mathrm{CC}=209+22 \mathrm{bp})\end{array}$ \\
\hline $\begin{array}{l}\text { P23-SNP3 } \\
(\text { g.205468C }>\text { T) }\end{array}$ & $\begin{array}{l}\text { F: GATTATTGTGCCAGGAAGCC } \\
\text { R: GATCTGAACCCAAAGACTGAA }\end{array}$ & 60 & 714 & $\begin{array}{l}\text { PCR-RFLP }(\mathrm{DdeI}) \\
(\mathrm{CC}=589 \text { bp; CT }=589+440 \\
\text { bp; TT }=440 \mathrm{bp})\end{array}$ \\
\hline $\begin{array}{l}\text { P25-SNP5 } \\
(\text { g.297690C }<\mathrm{T})\end{array}$ & $\begin{array}{l}\text { F: TACAGCATCCTCTGCGTTCT } \\
\text { R: CCGTGCCTTCCACCTTGA }\end{array}$ & 60 & 1235 & $\begin{array}{l}\text { PCR-RFLP }(\text { HhaI }) \\
(\mathrm{TT}=594 \mathrm{bp} \\
\mathrm{CT}=594+564 \mathrm{bp} ; \\
\mathrm{CC}=564 \mathrm{bp})\end{array}$ \\
\hline
\end{tabular}

Note: the single nucleic acid that is underlined is different from the reference sequence, and the change is required for forced PCR-RFLP and T-ARMS-PCR primer designing. *AT: annealing temperature.

per cycle) was executed for PCR amplification. Then the products were genotyped using agarose gel electrophoresis directly.

\subsection{Statistical analysis}

Genotypic frequencies and allelic frequencies were calculated according to Botstein's method (Botstein et al., 1980). Population genetic diversity index, homozygosity (Ho), effective allele number $(\mathrm{Ne})$ and polymorphism information content (PIC) were calculated successively on the MSRcall website (http://www.msrcall.com/). Hardy-Weinberg equilibrium (HWE), linkage disequilibrium (LD) structure and haplotypes of the five SNP loci in Qinchuan and Jinnan breeds were calculated using the SHEsis program (http:// analysis.bio-X.cn) (Li et al., 2009; Q. Yang et al., 2016).

The relationship between genotypes, haplotypes and the growth traits in Qinchuan and Jinnan populations were analyzed using the SPSS software (version 17.0) (IBM Corp., Armonk, NY, USA). Since all cattle were adult females and each breed was fed the same nutritional diet on their respective farms, the basic linear model $Y=\mu+G+e$ was used to determine the relationship between genotypes, haplotypes and growth traits for each breed. In the formulate, $Y$ denotes the trait data of each animal, $\mu$ the overall mean for each trait, $G$ the effect of genotype and $e$ the random error (Dang et al., 2014; Zhang et al., 2015a).

\section{Results}

\subsection{Novel SNP identification and genotyping of the bovine ATBF1 gene}

According to the sequence chromas, five novel SNPs (SNP1 to SNP5) were identified within the Qinchuan and Jinnan cattle ATBF1 gene (Fig. 1). Among them, SNP1 and SNP2 were synonymous mutations, which were located at exon 2 and exon 3, respectively. SNP1 and SNP2 loci code the 503th leucine and the 963th threonine of the cattle ATBF1 protein, respectively. SNP3 and SNP4 were located at intron 3, and SNP4 was close to the exon 4 splicing site (four base distances). SNP5 was a missense coding SNP at exon 9, resulting in the 2488th amino acid valine to alanine. The genotyping results can be seen from the agarose gel electrophoresis photos, which shows that SNP1-SNP5 were successfully genotyped by their own methods (Fig. 2).

\subsection{Genetic diversity analysis of the bovine ATBF1 gene}

Genotype frequency and allelic frequency were calculated according to the genotyping results. At the SNP1 locus, the frequency of allele $\mathrm{C}$ was distinctly higher than allele $\mathrm{G}$ in the two breeds. Genotype CC is the most prevalent. At the SNP2 locus, the frequency of TT was significantly higher than the other genotypes. At the SNP3 locus, the frequency of allele T is higher than C. At the SNP4 locus, there was no 


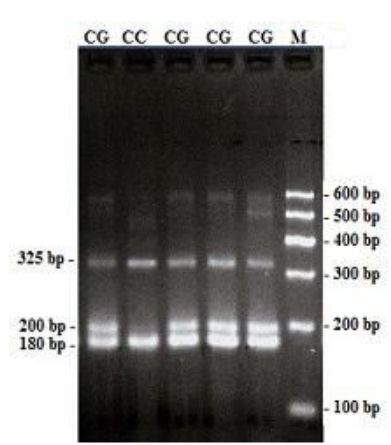

SNP1

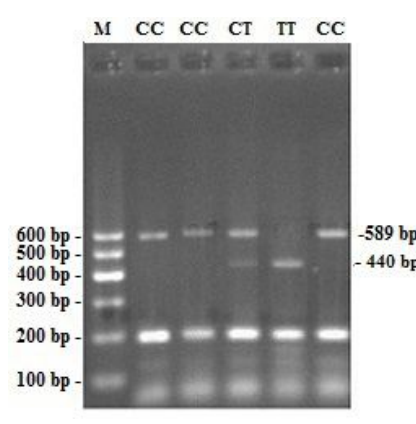

SNP3

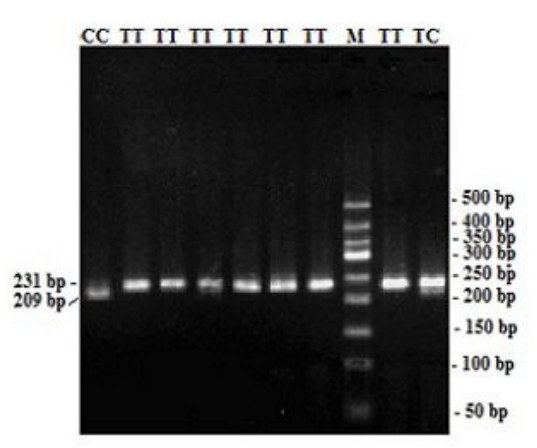

SNP2

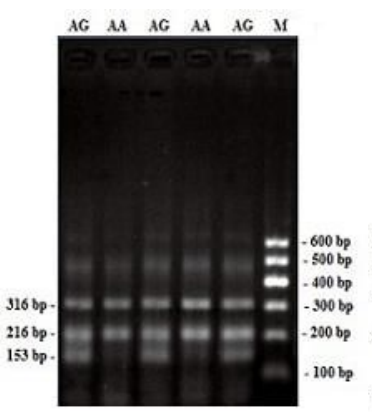

SNP4

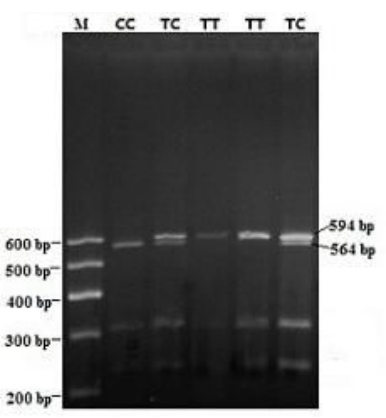

SNP5

Figure 2. Agarose gel electrophoresis patterns of five novel SNPs of the bovine ATBF1 gene. Note that the letter "M" above the figure represents the DNA marker.

GG genotype, and the frequency of AG was higher than AA. At the SNP5 locus, genotype frequency of the heterozygote was higher than the other genotypes, and the frequency of allele $\mathrm{T}$ was higher than $\mathrm{C}$ (Table 3 ).

The genetic diversity parameters Ho, Ne and PIC of the five loci of the Qinchuan and Jinnan populations were calculated and are shown in Table 3. These results suggest that these loci are polymorphic in these two cattle breeds. However, the values of PIC suggest that these loci are low polymorphisms $(0<\mathrm{PIC}<0.25)$ and intermediate polymorphisms $(0.25<$ PIC < 0.5) (Table 3) (Pan et al., 2013). The HardyWeinberg equilibrium $P$ value shows that some loci were at Hardy-Weinberg equilibrium $(P>0.05)$ and some were in disequilibrium $(P<0.05)$.

\subsection{Haplotype and linkage disequilibrium analysis of the five SNP loci}

Haplotype pairwise linkage disequilibrium analysis indicated that there were a total of 18 haplotypes in Qinchuan and Jinnan cattle. Among these haplotypes, seven were shared by these two populations. Nine haplotypes were unique to Qinchuan cattle and two haplotypes were unique to Jinnan cattle. The frequencies of the haplotypes showed that Hap 7 (CTCGT) and Hap 5 (CTCAT) were the main haplotypes in the Qinchuan and Jinnan cattle populations, respectively (Table 4). Based on the $D^{\prime}$ and $r^{2}$ values, three closely linked loci were revealed in the Qinchuan breed and five were revealed in the Jinnan breed (Fig. 3). The $D^{\prime}$ values were 0.756 (SNP1 and SNP3), 0.608 (SNP1 and SNP4) and 0.624 (SNP2 and SNP5) in the Qinchuan cattle breed. In the Jinnan cattle breed, the $D^{\prime}$ values were 0.640 (SNP1 and SNP3), 0.999 (SNP1 and SNP4), 0.997 (SNP2 and SNP4), 1.000 (SNP3 and SNP4) and 0.696 (SNP4 and SNP5) (Fig. 3). Thus, we further analyzed the effects of the combined genotypes above and growth traits in cattle.

\subsection{Relationships between the genetic variations and growth-related traits}

Association analysis found that different genotypes of the SNP1 locus were similar, with a significant association with the height across the hip in Qinchuan cattle $(P=0.05)$, and the heterozygote carriers had the highest value (Table 5). At the SNP2 locus, the different genotypes were significantly associated with chest circumference and body side length traits in Jinnan cattle, and the CC genotype carriers had the highest growth trait index (Table 5). For SNP3, the different genotypes were found to have a significant association with chest width, chest depth and hucklebone width growth traits, 

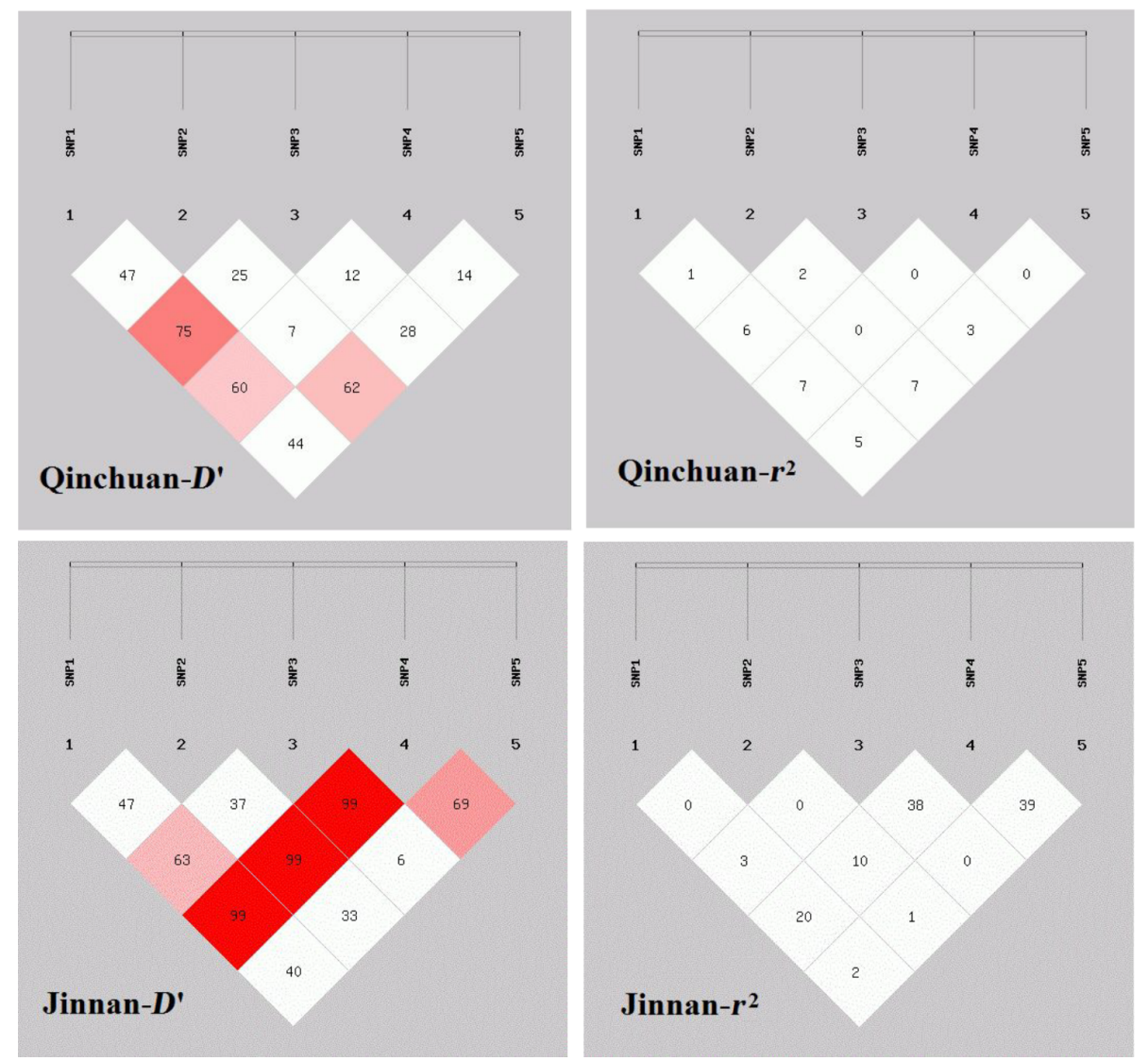

Figure 3. Linkage disequilibrium (LD) plot $\left(D^{\prime}\right.$ and $\left.r^{2}\right)$ of five novel SNP loci within the ATBF1 gene in Qinchuan and Jinnan cattle.

and CC carriers had the best growth trait index in Qinchuan cattle. Moreover, the genotypes had a similar significant association with body height $(P=0.05)$, and the heterozygote carriers had the best value in Qinchuan cattle (Table 5). However, no significant association between different genotypes of SNP4 and SNP5 loci and growth-related traits were found.

The association analysis found that three and one combined genotypes were associated with growth traits in Qinchuan and Jinnan breeds, respectively. At the SNP1SNP3 loci, the combined genotype CG-CC carriers had significantly wider chests than the CC-TT carriers in the Qinchuan breed $(P<0.05)$ (Table 6). At the SNP1-SNP4 loci, the CG-AG carriers had a higher height across the hip than CC-AA carriers in the Qinchuan breed $(P=0.05)$ (Table 6). For the SNP2-SNP5 loci in Qinchuan cattle, TC$\mathrm{CC}$ had the smallest chest circumference, chest width and hucklebone width values among all the combined genotypes $(P<0.05)$ (Table 6). For the SNP1-SNP3 loci in Jinnan cattle, CG-CT carriers had the smallest body height, height across the hip and body side length, and CG-CC had the largest chest circumference and rump length, among all the combined genotypes (Table 6). In addition, no significant association was found between the other combined genotypes and growth-related traits.

\section{Discussion}

Due to the important roles of ATBF1 in regulating myogenesis and adipose tissue development and its close relationship with the HPA axis and JAK-STAT pathways in livestock science (Huang et al., 2015; Jiang et al., 2014; S. F. Yang et al., 2016; Zhao et al., 2016), ATBF1 was chosen as the candidate gene. In this study, we recovered five SNPs in the bovine $A T B F 1$ gene for the first time. Three novel SNPs were exonic, while the other two novel SNPs were intronic. For individual genotype identification, three methods, namely PCR-RFLP, forced PCR-RFLP and T-ARMS-PCR, were applied. For the SNP locus, where the nucleotide sequence could be recognized using restriction enzymes, the PCR-RFLP method can be used to identify individual genotypes (Wang et al., 2013). For the SNP locus without the sequence that could be recognized using restriction enzymes, the forced PCR-RFLP primers were designed. This method needs to change one or two nucleotides, which are close to the SNP locus, to make this sequence recognizable using restriction enzymes and genotyping (Huang et al., 2014). For the SNP locus, which is difficult to genotype using the two methods above, T-ARMS-PCR is available ( $\mathrm{Li}$ et al., 2014; Wang et al., 2014; Zhang et al., 2015a). 
Table 3. Genotype, allelic distribution and genetic diversity of five SNP loci of the bovine ATBF1 gene.

\begin{tabular}{|c|c|c|c|c|c|c|c|c|c|}
\hline \multirow{3}{*}{$\begin{array}{l}\text { Locus/ } \\
\text { Breed } \\
\text { SNP1 }\end{array}$} & \multirow{2}{*}{\multicolumn{3}{|c|}{$\begin{array}{l}\text { Genotype frequency } \\
\text { (Number of animals) }\end{array}$}} & \multirow{2}{*}{\multicolumn{2}{|c|}{$\begin{array}{c}\text { Allelic } \\
\text { frequency }\end{array}$}} & \multirow{3}{*}{$\begin{array}{l}P \text { value } \\
(\mathrm{HWE})^{\mathrm{a}}\end{array}$} & \multicolumn{3}{|c|}{ Diversity parameters $b$} \\
\hline & & & & & & & \multirow[t]{2}{*}{ Ho } & \multirow[t]{2}{*}{$\mathrm{Ne}$} & \multirow[t]{2}{*}{$\mathrm{PIC}$} \\
\hline & $\mathrm{CC}(n)$ & $\mathrm{CG}(n)$ & $\mathrm{GG}(n)$ & $\mathrm{C}$ & G & & & & \\
\hline Qinchuan & $0.556(60)$ & 0.407 (44) & 0.037 (4) & 0.759 & 0.241 & $P>0.05$ & 0.634 & 1.576 & 0.299 \\
\hline Jinnan & $0.721(111)$ & $0.221(34)$ & $0.058(9)$ & 0.831 & 0.169 & $P<0.05$ & 0.719 & 1.390 & 0.241 \\
\hline SNP2 & $\mathrm{TT}(n)$ & $\mathrm{TC}(n)$ & $\mathrm{CC}(n)$ & $\mathrm{T}$ & $\mathrm{C}$ & & & & \\
\hline Qinchuan & $0.794(247)$ & $0.196(61)$ & $0.010(3)$ & 0.892 & 0.108 & $P>0.05$ & 0.808 & 1.238 & 0.174 \\
\hline Jinnan & $0.836(153)$ & $0.148(27)$ & $0.016(3)$ & 0.910 & 0.090 & $P>0.05$ & 0.836 & 1.196 & 0.151 \\
\hline SNP3 & $\mathrm{CC}(n)$ & $\mathrm{CT}(n)$ & $\mathrm{TT}(n)$ & $\mathrm{C}$ & $\mathrm{T}$ & & & & \\
\hline Qinchuan & $0.528(171)$ & $0.457(148)$ & $0.015(5)$ & 0.756 & 0.244 & $P<0.05$ & 0.631 & 1.584 & 0.301 \\
\hline Jinnan & $0.486(90)$ & $0.459(85)$ & $0.054(10)$ & 0.716 & 0.284 & $P>0.05$ & 0.595 & 1.680 & 0.323 \\
\hline SNP4 & $\mathrm{AA}(n)$ & $\mathrm{AG}(n)$ & $\mathrm{GG}(n)$ & A & G & & & & \\
\hline Qinchuan & $0.420(21)$ & $0.580(29)$ & $0(0)$ & 0.710 & 0.290 & $P<0.05$ & 0.588 & 1.700 & 0.327 \\
\hline Jinnan & $0.227(40)$ & $0.773(136)$ & $0(0)$ & 0.614 & 0.386 & $P<0.05$ & 0.526 & 1.902 & 0.362 \\
\hline SNP5 & $\mathrm{CC}(n)$ & $\mathrm{TC}(n)$ & $\mathrm{TT}(n)$ & $\mathrm{C}$ & $\mathrm{T}$ & & & & \\
\hline Qinchuan & $0.202(58)$ & $0.453(130)$ & 0.345 (99) & 0.429 & 0.571 & $P>0.05$ & 0.510 & 1.960 & 0.370 \\
\hline Jinnan & $0.227(42)$ & $0.459(85)$ & $0.314(58)$ & 0.457 & 0.543 & $P>0.05$ & 0.504 & 1.986 & 0.373 \\
\hline
\end{tabular}

Note: ${ }^{a} P$ value (HWE): Hardy-Weinberg equilibrium $P$ value.

b Diversity parameters: Ho: gene homozygosity; Ne: effective allele numbers; PIC: polymorphism information content.

Table 4. Haplotype frequency within the $A T B F 1$ gene in Qinchuan and Jinnan cattle.

\begin{tabular}{|c|c|c|c|c|c|c|c|c|}
\hline \multirow[t]{2}{*}{ Haplotype name } & \multirow[t]{2}{*}{ SNP1 } & \multirow[t]{2}{*}{ SNP2 } & \multirow[t]{2}{*}{ SNP3 } & \multirow[t]{2}{*}{ SNP4 } & \multirow[t]{2}{*}{ SNP5 } & \multirow[t]{2}{*}{ Haplotype } & \multicolumn{2}{|c|}{ Haplotype frequencies } \\
\hline & & & & & & & Qinchuan cattle & Jinnan cattle \\
\hline Hap 1 & $\mathrm{C}$ & $\mathrm{C}$ & $\mathrm{C}$ & A & $\mathrm{C}$ & CCCAC & 0.052 & 0 \\
\hline Hap 2 & $\mathrm{C}$ & $\mathrm{C}$ & $\mathrm{T}$ & A & $\mathrm{T}$ & ССТАТ & 0.030 & 0 \\
\hline Hap 3 & $\mathrm{C}$ & $\mathrm{C}$ & $\mathrm{T}$ & $\mathrm{G}$ & $\mathrm{C}$ & CCTGC & 0.040 & 0.050 \\
\hline Hap 4 & $\mathrm{C}$ & $\mathrm{T}$ & $\mathrm{C}$ & A & $\mathrm{C}$ & CTCAC & 0.129 & 0.059 \\
\hline Hap 5 & $\mathrm{C}$ & $\mathrm{T}$ & $\mathrm{C}$ & A & $\mathrm{T}$ & CTCAT & 0.129 & 0.391 \\
\hline Hap 6 & $\mathrm{C}$ & $\mathrm{T}$ & $\mathrm{C}$ & $\mathrm{G}$ & $\mathrm{C}$ & CTCGC & 0.049 & 0.100 \\
\hline Hap 7 & $\mathrm{C}$ & $\mathrm{T}$ & $\mathrm{C}$ & $\mathrm{G}$ & $\mathrm{T}$ & CTCGT & 0.163 & 0 \\
\hline Hap 8 & $\mathrm{C}$ & $\mathrm{T}$ & $\mathrm{T}$ & A & $\mathrm{C}$ & CTTAC & 0.111 & 0 \\
\hline Hap 9 & $\mathrm{C}$ & $\mathrm{T}$ & $\mathrm{T}$ & $\mathrm{G}$ & $\mathrm{C}$ & CTTGC & 0.001 & 0.100 \\
\hline Hap 10 & $\mathrm{G}$ & $\mathrm{C}$ & $\mathrm{C}$ & A & $\mathrm{T}$ & GCCAT & 0.022 & 0.150 \\
\hline Hap 11 & $\mathrm{G}$ & $\mathrm{C}$ & $\mathrm{C}$ & $\mathrm{G}$ & $\mathrm{C}$ & GCCGC & 0.014 & 0 \\
\hline Hap 12 & G & $\mathrm{C}$ & $\mathrm{T}$ & A & $\mathrm{T}$ & GCTAT & 0.018 & 0 \\
\hline Hap 13 & $\mathrm{G}$ & $\mathrm{T}$ & $\mathrm{C}$ & A & $\mathrm{C}$ & GTCAC & 0.048 & 0.050 \\
\hline Hap 14 & G & $\mathrm{T}$ & $\mathrm{C}$ & A & $\mathrm{T}$ & GTCAT & 0.135 & 0 \\
\hline Hap 15 & $\mathrm{G}$ & $\mathrm{T}$ & $\mathrm{C}$ & $\mathrm{G}$ & $\mathrm{C}$ & GTCGC & 0.044 & 0 \\
\hline Hap 16 & G & $\mathrm{T}$ & $\mathrm{T}$ & A & $\mathrm{T}$ & GTTAT & 0.017 & 0 \\
\hline Hap 17 & G & $\mathrm{T}$ & $\mathrm{T}$ & G & $\mathrm{C}$ & GTTGC & 0 & 0.041 \\
\hline Hap 18 & $\mathrm{G}$ & $\mathrm{T}$ & $\mathrm{T}$ & $\mathrm{G}$ & $\mathrm{T}$ & GTTGT & 0 & 0.059 \\
\hline
\end{tabular}

The preferred methods are PCR-RFLP and forced PCRRFLP because they are more accurate and mature than TARMS-PCR (Cai et al., 2013; Sun et al., 2013). T-ARMSPCR is easy to operate, using less time and money, but the accuracy is lower than the other two methods. This study performed both PCR-RFLP and T-ARMS-PCR methods to calculate the accuracy of them (Li et al., 2014). The result showed that the consistency of these two methods is $98.8 \%$, $40 \%$ of inconsistency was caused by PCR-RFLP and $60 \%$ of inconsistency was caused by the T-ARMS-PCR method (Li 
Table 5. Association of $A T B F 1$ gene SNP3 genotypes and cattle growth traits.

\begin{tabular}{llrrrrr}
\hline Locus/breed & Growth trait & \multicolumn{2}{c}{${\text { Observed genotypes }(\mathrm{LSM} \pm \mathrm{SE})^{*}}$} & $P$ value \\
\hline SNP1 & & $\mathrm{CC}$ & $\mathrm{CG}$ & $\mathrm{GG}$ \\
\hline Qinchuan & height across the hip & $124.75^{\mathrm{ab}} \pm 1.07$ & $127.34^{\mathrm{a}} \pm 1.13$ & $122.67^{\mathrm{b}} \pm 1.45$ & $P=0.05$ \\
\hline SNP2 & & $\mathrm{TT}$ & $\mathrm{TC}$ & $\mathrm{CC}$ \\
\hline Jinnan & chest circumference & $183.77^{\mathrm{b}} \pm 1.26$ & $185.04^{\mathrm{ab}} \pm 2.84$ & $201.33^{\mathrm{a}} \pm 5.55$ & $P<0.05$ \\
Jinnan & body side length & $151.50^{\mathrm{ab}} \pm 0.99$ & $150.88^{\mathrm{b}} \pm 1.63$ & $158.00^{\mathrm{a}} \pm 2.00$ & $P<0.05$ \\
\hline SNP3 & & $\mathrm{CC}$ & $\mathrm{CT}$ & $\mathrm{TT}$ & \\
\hline Qinchuan & body height & $128.88^{\mathrm{ab}} \pm 0.51$ & $129.27^{\mathrm{a}} \pm 0.64$ & $124.00^{\mathrm{b}} \pm 2.72$ & $P=0.05$ \\
Qinchuan & chest width & $38.25^{\mathrm{a}} \pm 0.44$ & $38.37^{\mathrm{a}} \pm 0.44$ & $33.90^{\mathrm{b}} \pm 0.95$ & $P<0.05$ \\
Qinchuan & chest depth & $64.20^{\mathrm{A}} \pm 0.51$ & $64.21^{\mathrm{A}} \pm 0.60$ & $59.60^{\mathrm{B}} \pm 0.93$ & $P<0.01$ \\
Qinchuan & hucklebone width & $43.21^{\mathrm{a}} \pm 0.43$ & $41.96^{\mathrm{b}} \pm 0.48$ & $41.80^{\mathrm{ab}} \pm 1.83$ & $P=0.05$ \\
\hline
\end{tabular}

Note: * $(\mathrm{LSM} \pm \mathrm{SE}), \mathrm{LSM}$ : least squares mean; SE: standard error. The LSM values with different superscripts within the same row differ significantly at $P<0.05$ for a and $\mathrm{b}$ and $P<0.01$ for $\mathrm{A}$ and $\mathrm{B}$.

Table 6. Associations between combined genotypes and growth traits in Qinchuan and Jinnan cattle.

\begin{tabular}{|c|c|c|c|c|c|c|c|c|}
\hline Loci/breed & Growth traits & Col & bined genotypes ( & umber)/observed g & notypes (LSM $\pm \mathrm{S}$ & & & $P$ value \\
\hline SNP1-SNP3 & & CC-CC (24) & CC-CT (24) & CC-TT (4) & CG-CC (21) & CG-CT (13) & & \\
\hline Qinchuan & chest width & $39.69^{\mathrm{ab}} \pm 1.22$ & $38.00^{\mathrm{ab}} \pm 1.26$ & $34.38^{\mathrm{b}} \pm 1.07$ & $39.83^{\mathrm{a}} \pm 1.18$ & $38.54^{\mathrm{ab}} \pm 1.29$ & & $P<0.05$ \\
\hline SNP1-SNP4 & & CC-AA (6) & CC-AG (12) & & CG-AA (6) & CG-AG (11) & & \\
\hline Qinchuan & height across the hip & $122.67^{b} \pm 2.32$ & $124.25^{\mathrm{ab}} \pm 1.99$ & & $125.00^{\mathrm{ab}} \pm 2.45$ & $129.09^{\mathrm{a}} \pm 1.90$ & & $P=0.05$ \\
\hline SNP2-SNP5 & & TT-CC (26) & TT-CT (76) & TT-TT (70) & TC-CC (17) & TC-CT (26) & TC-TT (7) & \\
\hline Qinchuan & chest circumference & $178.40^{\mathrm{A}} \pm 2.99$ & $177.86^{\mathrm{A}} \pm 3.06$ & $177.41^{\mathrm{A}} \pm 3.11$ & $151.76^{\mathrm{B}} \pm 14.62$ & $180.23^{\mathrm{A}} \pm 3.07$ & $181.43^{\mathrm{A}} \pm 5.22$ & $P<0.01$ \\
\hline Qinchuan & chest width & $37.94^{\mathrm{ab}} \pm 0.91$ & $38.07^{\mathrm{ab}} \pm 0.74$ & $38.43^{\mathrm{ab}} \pm 0.59$ & $35.82^{\mathrm{b}} \pm 1.43$ & $39.31^{\mathrm{a}} \pm 1.04$ & $38.29^{\mathrm{ab}} \pm 1.25$ & $P<0.05$ \\
\hline Qinchuan & hucklebone width & $23.90^{\mathrm{a}} \pm 0.91$ & $23.68^{\mathrm{a}} \pm 0.74$ & $23.10^{\mathrm{ab}} \pm 0.59$ & $21.53^{\mathrm{b}} \pm 1.43$ & $23.87^{\mathrm{a}} \pm 1.04$ & $22.79^{\mathrm{ab}} \pm 1.25$ & $P<0.05$ \\
\hline SNP1-SNP3 & & CC-CC (40) & CC-CT (56) & CC-TT (7) & CG-CC (17) & CG-CT (12) & GG-CC (6) & \\
\hline Jinnan & body height & $127.70^{\mathrm{ab}} \pm 0.93$ & $129.41^{\mathrm{ab}} \pm 0.85$ & $129.57^{\mathrm{ab}} \pm 1.76$ & $131.18^{\mathrm{a}} \pm 2.02$ & $125.83^{\mathrm{b}} \pm 1.63$ & $127.33^{\mathrm{ab}} \pm 1.45$ & $P<0.05$ \\
\hline Jinnan & height across the hip & $130.43^{\mathrm{ab}} \pm 1.23$ & $132.04^{\mathrm{ab}} \pm 0.94$ & $134.00^{\mathrm{ab}} \pm 2.06$ & $133.76^{\mathrm{a}} \pm 2.37$ & $127.58^{b} \pm 1.89$ & $128.50^{\mathrm{ab}} \pm 2.60$ & $P<0.05$ \\
\hline Jinnan & body side length & $186.00^{\mathrm{b}} \pm 1.97$ & $151.68^{\mathrm{ab}} \pm 1.59$ & $151.71^{\mathrm{ab}} \pm 4.83$ & $155.47^{\mathrm{a}} \pm 2.35$ & $144.67^{b} \pm 3.60$ & $148.33^{\mathrm{ab}} \pm 4.29$ & $P<0.05$ \\
\hline Jinnan & chest circumference & $152.60^{\mathrm{ab}} \pm 2.67$ & $185.50^{\mathrm{ab}} \pm 1.86$ & $184.29^{\mathrm{ab}} \pm 5.59$ & $188.59^{\mathrm{a}} \pm 4.13$ & $177.08^{\mathrm{b}} \pm 4.09$ & $177.83^{\mathrm{ab}} \pm 5.24$ & $P<0.05$ \\
\hline Jinnan & rump length & $47.86^{\mathrm{ab}} \pm 0.90$ & $47.83^{b} \pm 0.63$ & $46.43^{\mathrm{ab}} \pm 1.82$ & $50.71^{\mathrm{a}} \pm 0.99$ & $45.36^{\mathrm{b}} \pm 0.89$ & $47.00^{\mathrm{ab}} \pm 3.61$ & $P<0.05$ \\
\hline
\end{tabular}

Note: ${ }^{*}(\mathrm{LSM} \pm \mathrm{SE}), \mathrm{LSM}$ : least squares mean; SE: standard error. The LSM values with different superscripts within the same row differ significantly at $P<0.05$ for a and $\mathrm{b}$ and $P<0.01$ for A and $\mathrm{B}$.

et al., 2014). Our previous study also identified that the accuracy of T-ARMS-PCR and PCR-RFLP reached 99.07 and $99.69 \%$, respectively, based on the sequencing result (Zhang et al., 2015a).

Genetic diversity analysis found that three loci were not at Hardy-Weinberg equilibrium. The disequilibrium of SNP4 in the two breeds may be caused by the deficiency of genotype GG. A possible explanation for the disequilibrium is that artificial selection promotes the mutation of these loci, and these mutations only happened a few generations ago.

The association analysis found that the synonymous coding SNPs, SNP1 and SNP2, were associated with three growth-related traits. There are studies that have the same results as this study, which are that coding SNPs are associated with economically important production traits. For example, the synonymous mutation AC_000163:g.18161C >G SNP in the goat PITX2 gene is associated with milk density in the Guanzhong dairy goat (Zhao et al., 2013). The synonymous mutation might produce codon usage bias, thereby influencing the production traits (Lan et al., 2007).

Furthermore, the different genotypes of intronic variation SNP3 were significantly associated with four growthrelated traits in Qinchuan cattle. The combined genotypes containing the SNP3 locus were significantly associated with chest width in the Qinchuan breed and five other traits in the Jinnan breed. Studies showed that the intronic mutation G3072A in sheep IGF2 was associated with skeletal muscle development (Cockett et al., 1994) and the intronic mutation AC_000163:g.18353TNC in the goat PITX2 gene was associated with more than 10 milk production traits (Zhao et al., 2013). The intronic mutation might affect the binding of the DNA sequence and DNA binding factors, such as transcrip- 
tion factors and splicing factors. Moreover, intronic mutation might influence the transcriptional efficiency as well as stability of mRNA (Zhao et al., 2013).

Furthermore, association analysis of genotypes of single SNP loci and growth-related traits is an important way to evaluate the effects of a gene in animal breeding. However, the association analysis between combined genotypes and growth related traits will be more reliable and efficient for evaluating the effects of genetic variations in a gene (Akey et al., 2001; Schaid, 2004). Thus, we analyzed the association between the combined genotypes with higher $D^{\prime}$ value and growth straits. A total of three different combined genotypes were found to have effects on four and five different growth traits in Qinchuan and Jinnan cattle, respectively. These results demonstrated the important roles of ATBF1 single-nucleotide variations in cattle.

\section{Conclusions}

In the present study, three novel SNPs (SNP1, SNP2 and SNP3) and three combined genotypes (SNP1-SNP3, SNP1SNP4 and SNP2-SNP5) in the ATBF1 gene were significantly associated with growth-related traits in cattle. SNP1 was similarly significantly associated with the height across the hip in Qinchuan cattle $(P=0.05)$, and the heterozygote carriers had the highest value. SNP2 was significantly associated with chest circumference $(P<0.05)$ and body side length traits $(P<0.05)$ in Jinnan cattle, and the CC genotype carriers had the highest growth trait index. For SNP3, associations between ATBF1 genotypes and body height $(P=0.05)$, chest width $(P<0.05)$, chest depth $(P<0.01)$ and hucklebone width $(P=0.05)$ of Qinchuan cattle were found, and CC carriers had the best growth trait indexes for the first three traits. Moreover, a total of three different combined genotypes (SNP1-SNP3, SNP1-SNP4 and SNP2SNP5) were found to have effects on four and five different growth traits in Qinchuan and Jinnan cattle, respectively. Thus, SNP1, SNP2 and SNP3 have the potential to be useful DNA markers for the improvement of growth-related traits in cattle.

Data availability. The original data are available upon request to the corresponding authors.

Competing interests. The authors declare that they have no conflict of interest.

Acknowledgements. This work was supported by the National Natural Science Foundation of China (no. 31672400), Science and Technology Coordinator Innovative engineering projects of Shaanxi Province (2014KTZB02-02-02-02) and the Program of National Beef Cattle and Yak Industrial Technology System (no.
CARS-37).

Edited by: Steffen Maak

Reviewed by: Faruk Balci and one anonymous referee

\section{References}

Akey, J., Jin, L., and Xiong, M.: Haplotypes vs single marker linkage disequilibrium tests: what do we gain?, Eur. J. Hum. Genet., 9, 291-300, 2001.

Araujo, R. V., Chang, C. V., Cescato, V. A., Fragoso, M. C., Bronstein, M. D., Mendonca, B. B., Arnhold, I. J., and Carvalho, L. R.: PROP1 overexpression in corticotrophinomas: evidence for the role of PROP1 in the maintenance of cells committed to corticotrophic differentiation, Clinics., 68, 887-891, 2013.

Botstein, D., White, R. L., Skolnick, M., and Davis, R. W.: Construction of a genetic linkage map in man using restriction fragment length polymorphisms, Am. J. Hum. Genet., 32, 314-331, 1980.

Cai, H., Lan, X., Li, A., Zhou, Y., Sun, J., Lei, C., Zhang, C., and Chen, H.: SNPs of bovine HGF gene and their association with growth traits in Nanyang cattle, Res. Vet. Sci., 95, 483-488, 2013.

Cockett, N. E., Jackson, S. P., Shay, T. L., Nielsen, D., Moore, S. S., Steele, M. R., Barendse, W., Green, R. D., and Georges, M.: Chromosomal localization of the callipyge gene in sheep (Ovis aries) using bovine DNA markers, P. Natl. Acad. Sci. USA, 91, 3019-3023, 1994.

Collins, A.: Primer1: primer design web service for tetra-primer ARMS-PCR, Open Bioinformatics Journal, 6, 55-58, 2012.

Dang, Y., Li, M., Yang, M., Cao, X., Lan, X., Lei, C., Zhang, C., Lin, Q., and Chen, H.: Identification of bovine NPC1 gene cSNPs and their effects on body size traits of Qinchuan cattle, Gene., 540, 153-160, 2014.

Davis, S. W., Castinetti, F., Carvalho, L. R., Ellsworth, B. S., Potok, M. A., Lyons, R. H., Brinkmeier, M. L., Raetzman, L. T., Carninci, P., Mortensen, A. H., Hayashizaki, Y., Arnhold, I. J., Mendonca, B. B., Brue, T., and Camper, S. A.: Molecular mechanisms of pituitary organogenesis: In search of novel regulatory genes, Mol Cell Endocrinol., 323, 4-19, 2010.

Herrington, J., Smit, L. S., Schwartz, J., and Carter-Su, C.: The role of STAT proteins in growth hormone signaling, Oncogene., 19, 2585-2597, 2000.

Huang, Y. Z., Zhan, Z. Y., Li, X. Y., Wu, S. R., Sun, Y. J., Xue, J., Lan, X. Y., Lei, C. Z., Zhang, C. L., Jia, Y. T., and Chen, H.: SNP and haplotype analysis reveal IGF2 variants associated with growth traits in Chinese Qinchuan cattle, Mol. Biol. Rep., 41, 591-598, 2014.

Huang, Y., Wang, C., Yao, Y., Zuo, X., Chen, S., Xu, C., Zhang, H., Lu, Q., Chang, L., Wang, F., Wang, P., Zhang, R., Hu, Z., Song, Q., Yang, X., Li, C., Li, S., Zhao, Y., Yang, Q., Yin, D., Wang, X., Si, W., Li, X., Xiong, X., Wang, D., Huang, Y., Luo, C., Li, J., Wang, J., Chen, J., Wang, L., Wang, L., Han, M., Ye, J., Chen, F., Liu, J., Liu, Y., Wu, G., Yang, B., Cheng, X., Liao, Y., Wu, Y., Ke, T., Chen, Q., Tu, X., Elston, R., Rao, S., Yang, Y., Xia, Y., and Wang, Q. K.: Molecular basis of gene-gene interaction: cyclic cross-regulation of gene expression and post-GWAS genegene interaction involved in atrial fibrillation, PLoS Genet., 11, e1005393, https://doi.org/10.1371/journal.pgen.1005393, 2015. 
Jia, W., Wu, X., Li, X., Xia, T., Lei, C., Chen, H., Pan, C., and Lan, X.: Novel genetic variants associated with mRNA expression of signal transducer and activator of transcription 3 (STAT3) gene significantly affected goat growth traits, Small Ruminant Research, 129, 25-36, 2015.

Jiang, Q., Ni, B., Shi, J., Han, Z., Qi, R., Xu, W., Wang, D., Wang, D. W., and Chen, M.: Down-regulation of ATBF1 activates STAT3 signaling via PIAS3 in pacing-induced HL-1 atrial myocytes, Biochem. Biophys. Res. Commun., 449, 278-283, 2014.

Jung, C. G., Kim, H. J., Kawaguchi, M., Khanna, K. K., Hida, H., Asai, K., Nishino, H., and Miura, Y.: Homeotic factor ATBF1 induces the cell cycle arrest associated with neuronal differentiation, Development, 132, 5137-5145, 2005.

Kawaguchi, M., Hara, N., Bilim, V., Koike, H., Suzuki, M., Kim, T. S., Gao, N., Dong, Y., Zhang, S., Fujinawa, Y., Yamamoto, O., Ito, H., Tomita, Y., Naruse, Y., Sakamaki, A., Ishii, Y., Tsuneyam, K., Inoue, M., Itoh, J., Yasuda, M., Sakata, N., Jung, C. G., Kanazawa, S., Akatsu, H., Minato, H., Nojima, T., Asai, K., and Miura, Y.: A diagnostic marker for superficial urothelial bladder carcinoma: lack of nuclear ATBF1 (ZFHX3) by immunohistochemistry suggests malignant progression, BMC Cancer., 16, 805, 2016.

Lan, X. Y., Pan, C. Y., Chen, H., Zhang, C. L., Li, J. Y., Zhao, M., Lei, C. Z., Zhang, A. L., and Zhang, L.: An AluI PCR-RFLP detecting a silent allele at the goat POU1F1 locus and its association with production traits, Small Ruminant Research, 73, 8-12, 2007.

Lan, X. Y., Pan, C. Y., Li, J. Y., Guo, Y. W., Hu, S., Wang, J., Liu, Y. B., Hu, S. R., Lei, C. Z., and Chen, H.: Twelve novel SNPs of the goat POU1F1 gene and their associations with cashmere traits, Small Ruminant Research, 85, 116-121, 2009.

Lao, M., Shi, M., Zou, Y., Huang, M., Ye, Y., Qiu, Q., Xiao, Y., Zeng, S., Liang, L., Yang, X., and Xu, H.: Protein Inhibitor of Activated STAT3 Regulates Migration, Invasion, and Activation of Fibroblast-like Synoviocytes in Rheumatoid Arthritis, J. Immunol., 196, 596-606, 2016.

Li, M. X., Sun, X. M., Jiang, J., Sun, Y. J., Lan, X. Y., Lei, C. Z., and Chen, H.: Tetra-primer ARMS-PCR is an efficient SNP genotyping method: an example from SIRT2, Anal. Methods., 6, 18351840, 2014.

Li, Z., Zhang, Z., He, Z., Tang, W., Li, T., Zeng, Z., He, L., and Shi, Y.: Apartition-ligation-combination-subdivision EMalgorithm for haplotype inference with multiallelic markers: update of the SHEsis, Cell Res., 19, 519-523, 2009.

Liongue, C. and Ward, A. C.: Evolution of the JAK-STAT pathway, JAKSTAT., 2, e22756, https://doi.org/10.4161/jkst.22756, 2013.

Liu, Y., Ni, B., Lin, Y., Chen, X. G., Fang, Z., Zhao, L., Hu, Z., and Zhang, F.: Genetic polymorphisms in ZFHX3 are associated with atrial fibrillation in a Chinese Han population, PLoS One, 9, e101318, https://doi.org/10.1371/journal.pone.0101318, 2014.

Ma, L., Qin, Q. M., Yang, Q., Zhang, M., Zhao, H. Y., Pan, C. Y., Lei, C. Z., Chen, H., and Lan, X. Y.: Associations of six SNPs of POU1F1-PROP1-PITX1-SIX3 pathway genes with growth traits in two Chinese indigenous goat breeds, Ann. Anim. Sci., 17, 399-411, 2017.

Morinaga, T., Yasuda, H., Hashimoto, T., Higashio, K., and Tamaoki, T.: A human alpha-fetoprotein enhancer-binding pro- tein, ATBF1, contains four homeodomains and seventeen zinc fingers, Mol. Cell Biol., 11, 6041-6049, 1991.

Nojiri, S., Joh, T., Miura, Y., Sakata, N., Nomura, T., Nakao, H., Sobue, S., Ohara, H., Asai, K., and Ito, M.: ATBF1 enhances the suppression of STAT3 signaling by interaction with PIAS3, Biochem. Biophys. Res. Commun., 314, 97-103, 2004.

Pan, C., Wu, C., Jia, W., Xu, Y., Lei, C., Hu, S., Lan, X., and Chen, H.: A critical functional missense mutation (H173R) in the bovine PROP1 gene significantly affects growth traits in cattle, Gene., 531, 398-402, 2013.

Pedersen, L. D., Sørensen, A. C., and Berg, P.: Marker-assisted selection can reduce true as well as pedigree-estimated inbreeding, J. Dairy Sci., 92, 2214-2223, 2009.

Postigo, A. A. and Dean, D. C.: ZEB, a vertebrate homolog of Drosophila Zfh-1, is a negative regulator of muscle differentiation, EMBO J., 16, 3935-3943, 1997.

Postigo, A. A. and Dean, D. C.: Independent repressor domains in ZEB regulate muscle and T-cell differentiation, Mol. Cell Biol., 19, 7961-7971, 1999.

Qi, Y., Ranish, J. A., Zhu, X., Krones, A., Zhang, J., Aebersold, R., Rose, D. W., Rosenfeld, M. G., and Carriere, C.: Atbf1 is required for the Pit1 gene early activation, P. Natl. Acad. Sci. USA, 105, 2481-2486, 2008.

Richard, A. J. and Stephens, J. M.: The role of JAK-STAT signaling in adipose tissue function, Biochim. Biophys. Acta, 1842, 431439, 2014.

Schaid, D. J.: Evaluating associations of haplotypes with traits, Genet. Epidemiol., 27, 348-364, 2004.

Sun, X. M., Li. M. X., Li, A. M., Lan, X. Y., Lei, C. Z., Ma, W., Hua, L. S., Wang, J., Hu, S. R., and Chen, H.: Two novel intronic polymorphisms of bovine FGF21 gene are associated with body weight at 18 months in Chinese cattle, Livestock Science., 155, 23-29, 2013.

Sun, X., Fu, X., Li, J., Xing, C., Frierson, H. F., Wu, H., Ding, X., Ju, T., Cummings, R. D., and Dong, J. T.: Deletion of Atbf1/Zfhx3 in mouse prostate causes neoplastic lesions, likely by attenuation of membrane and secretory proteins and multiple signaling pathways, Neoplasia, 16, 377-389, 2014.

Sun, X., Xing, C., Fu, X., Li, J., Zhang, B., Frierson Jr., H. F., and Dong, J. T.: Additive Effect of Zfhx3/Atbf1 and Pten Deletion on Mouse Prostatic Tumorigenesis, J. Genet. Genomics., 42, 373382, 2015.

Trovato, L., Riccomagno, S., Prodam, F., Genoni, G., Walker, G. E., Moia, S., Bellone, S., and Bona, G.: Isolated GHD: investigation and implication of JAK/STAT related genes before and after rhGH treatment, Pituitary, 15, 482-489, 2012.

Tsai, C. T., Hsieh, C. S., Chang, S. N., Chuang, E. Y., Juang, J. M., Lin, L. Y., Lai, L. P., Hwang, J. J., Chiang, F. T., and Lin, J. L.: Next-generation sequencing of nine atrial fibrillation candidate genes identified novel de novo mutations in patients with extreme trait of atrial fibrillation, J. Med. Genet., 52, 28-36, 2015.

Wang, H. L., Li, Z. X., Wang, L. J., He, H., Yang, J., Chen, L., Niu, F. B., Liu, Y., Guo, J. Z., and Liu, X. L.: Polymorphism in PGLYRP-1 gene by PCR-RFLP and its association with somatic cell score in Chinese Holstein, Res. Vet. Sci., 95, 508-514, 2013.

Wang, Z. N., Li, M. J., Lan, X. Y., Li, M. X., Lei, Z. C., and Chen, H.: Tetra-primer ARMS-PCR identifies the novel genetic variations of bovine HNF- $4 \alpha$ gene associating with growth traits, Gene., 546, 206-213, 2014. 
Wu, X., Jia, W., Zhang, J., Li, X., Pan, C., Lei, C., Chen, H., Dang, R., and Lan X.: Determination of the novel genetic variants of goat STAT5A gene and their effects on body measurement traits in two Chinese native breeds, Small Ruminant Research, 121, 232-243, 2014.

Yang, Q., Zhang, S., Liu, L., Cao, X., Lei, C., Qi, X., Lin, F., Qu, W., Qi, X., Liu, J., Wang, R., Chen, H., and Lan, X.: Application of mathematical expectation (ME) strategy for detecting low frequency mutations: An example for evaluating 14-bp insertion/deletion (indel) within the bovine PRNP gene, Prion., 10, 409-419, 2016.

Yang, S. F., Hou, M. F., Chen, F. M., Ou-Yang, F., Wu, Y. C., Chai, C. Y., and Yeh, Y. T.: Prognostic value of protein inhibitor of activated STAT3 in breast cancer patients receiving hormone therapy, BMC Cancer, 16, 20, 2016.

Ye, S., Dhillon, S., Ke, X., Collins, A. R., and Day, I. N.: An efficient procedure for genotyping single nucleotide polymorphisms, Nucleic Acids Res., 29, E88, https://doi.org/10.1093/nar/29.17.e88, 2001.
Zhang, S., Dang, Y., Zhang, Q., Qin, Q., Lei, C., Chen, H., and Lan, X.: Tetra-primer amplification refractory mutation system PCR (T-ARMS-PCR) rapidly identified a critical missense mutation (P236T) of bovine ACADVL gene affecting growth traits, Gene., 559, 184-188, 2015a.

Zhang, X., Wu, X., Jia, W., Pan, C., Li, X., Lei, C., Chen, H., and Lan, X.: Novel Nucleotide Variations, Haplotypes Structure and Associations with Growth Related Traits of Goat AT MotifBinding Factor (ATBF1) Gene, Asian-Australas J. Anim. Sci., 28, 1394-1406, 2015b.

Zhao, H., Wu, X., Cai, H., Pan, C., Lei, C., Chen, H., and Lan, X.: Genetic variants and effects on milk traits of the caprine pairedlike homeodomain transcription factor 2 (PITX2) gene in dairy goats, Gene., 532, 203-210, 2013.

Zhao, D., Ma, G., Zhang, X., He, Y., Li, M., Han, X., Fu, L., Dong, X. Y., Nagy, T., Zhao, Q., Fu, L., and Dong, J. T.: Zinc Finger Homeodomain Factor Zfhx3 Is Essential for Mammary Lactogenic Differentiation by Maintaining Prolactin Signaling Activity, J. Biol. Chem., 291, 12809-12820, 2016. 